Artikel Penelitian

\title{
Peran Kearifan Lokal Nyunteng dalam Hubungan Sosial Petani Pangan di Desa Jatian Kecamatan Pakusari Kabupaten Jember
}

Nurul Dwi Novikarumsari' ${ }^{1}$,Risqi Annisatul ${ }^{2}$, Andrias Alfariski ${ }^{3}$, Zikil Muarrofah ${ }^{4}$, Arief Pamungkas ${ }^{5}, \mathbf{M}$. Nurhidayatullah ${ }^{6}$

12,3,4,5,6,7 Program Studi Penyuluhan Pertanian Fakulas Pertanian Universitas Jember, Jl. Kalimantan No.37 Krajan Timur Kec.Sumbersari, Jember Indonesia

corresponding author: nuruldwin@unej.ac.id

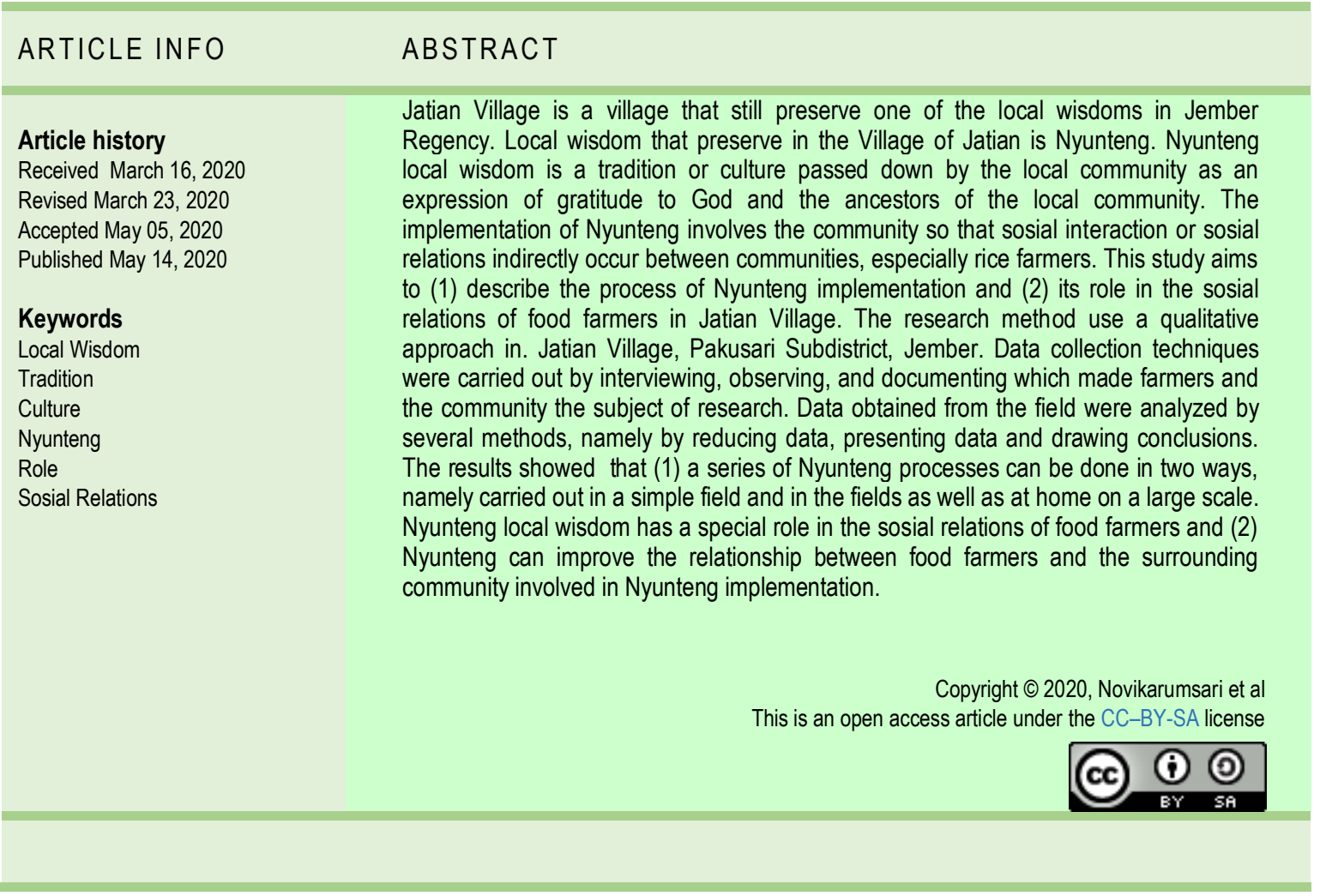

\section{PENDAHULUAN}

Sektor pertanian menjadi sektor utama di Indonesia karena merupakan negara yang terkenal akan sektor pertanian yang dimiliki, dimana kegiatan bertani atau bercocok tanam ini sudah ada sejak zaman prasejarah dan terus mengalami perkembangan hingga saat ini. Keberadaan dan perkembangan sektor pertanian sejak zaman prasejarah ini 
membuat sektor pertanian di Indonesia erat kaitannya dengan kebudayaan atau tradisi yang mereka percaya hingga saat ini.Kebudayaan atau tradisi yang mereka jalankan

tersebut kemudian menjadi kearifan lokal yang dimiliki daerah yang bersangkutan. Kearifan lokal dalam sektor pertanian tersebut tidak dapat hilang begitu saja seiring dengan perkembangan zaman, hal ini dapat dilihat dari banyaknya daerah-daerah di Indonesia yang masih mempertahankan kearifan lokal dalam melaksanakan usahataninya (Dila, 2017).

Subsektor tanaman pangan adalah subsektor tanaman pangan merupakan salah satu subsektor penting yang ada di lama sektor pertanian. Tanaman pangan memiliki potensi yang terbilang besar karena pada umumnya masyarakat membutuhkan tanaman pangan untuk memenuhi kebutuhan pangannya dalam kehidupan sehari - hari. Subsektor tanaman pangan terdiri atas beberapa komoditas diantaranya adalah padi, jagung, dan kedelai. Komoditas pangan yang menjadi komoditas unggulan masyarakat Indonesia adalah padi karena padi merupakan sumber bahan makanan pokok masyarakat Indonesia.

Menurut Guntur dkk (2016), Pembudidayaan tanaman padi di berbagai daerah Indonesia tidak selalu sama, karena budidaya disesuaikan dengan sistem yang digunakan. Masyarakat pedesaan pada umumnya masih menggunakan dan menerapkan budidaya padi dengan sistem tradisional. Sistem budidaya yang diterapkan oleh masyarakat petani di kawasan pedesaan diperoleh secara turun temurun. Sistem pengetahuan lokal memberikan gambaran mengenai kearifan tradisi masyarakat dalam mendayagunakan sumber daya alam dan sosial secara bijaksana yang mengacu pada keseimbangan dan kelestarian lingkungan.

Sistem pertanian tradisional tidak akan lepas dari kearifan lokal yang mengaitkan antara pertanian dengan kebudayaan, yang artinya dalam sektor pertanian masih terdapat sisi budaya yang terkandung di dalamnya. Masyarakat desa umumnya masih memegang teguh budaya yang berbentuk tradisi di dalam sektor pertanian. Kebudayaan dalam pertanian tentunya harus selalu dilestarikan agar kearifan lokal tetap terjaga. Kebudayaan berasal dari kata budaya yang berarti segala sesuatu yang melekat dalam sebuah masyarakat yang menjadi ciri khas masyarakat tersebut serta harus dilestarikan . Kebudayaan dalam pertanian umumnya berbentuk seperti tradisi, dimana hal tersebut dilakukan secara turun temurun (Edi dan Hastuti, 2015).

Kearifan lokal erat kaitannya dengan kebudayaan dan tradisi. Kearifan lokal merupakan tata nilai atau perilaku hidup masyarakat lokal dalam berinteraksi dengan lingkungan di sekitar tempatnya hidup secara arif. Kearifan lokal di setiap daerah berbeda-beda pada tempat dan waktu yang berbeda dan suku yang berbeda. Perbedaan ini disebabkan oleh kebutuhan hidupnya berbeda, sehingga pengalamannya dalam memenuhi kebutuhan hidupnya memunculkan berbagai sistem pengetahuan baik yang berhubungan dengan lingkungan maupun sosial. Petani mempunyai kearifan dalam kegiatan yang dilakukan dalam budidaya pertanian padi (Athanasius, 2015).

Menurut Sidabutar dkk (2016), kearifan lokal merupakan tata nilai atau perilaku hidup masyarakat lokal dalam berinteraksi dengan lingkungannya. Kearifan lokal tidak sama ada setiap masyarakat karena keadaan satu wilayah bisa jadi berbeda dengan wilayah lain. Perbedaan ini disebabkan karena adanya tantangan alam dan kebutuhan hidup yang berbeda-beda, sehingga pengalamannya dalam memenuhi kebututuhan hidup memunculkan berbagai sistem pengetahuan baik yang berhubungan dengan lingkungan maupun yang berhubungan dengan sosial.

Kebudayaan merupakan kompleks keseluruhan dari pengetahuan, keyakninan, kesenian, moral, hokum, adat istiadat, dan semua kemampuan dan kebiasaan yang lain yang diperoleh seseorang sebagai anggota masyarakat. Kebudayaan memiliki beberapa wujud yaitu:

1) Kebudayaan sebagai ide, gagasan, nilai, atau norma. 
2) Kebudayaan sebagai aktivitas atau pola tindakan manusia dalam bermasyarakat.

3) Kebudayaan sebagai benda hasil cipta, karya, tindakan, tidakan, aktivitas, atau manusia dalam bermasyarakat.

Tradisi merupakan suatu kearifan lokal yang termasuk ke dalam wujud kebudayaan. Tradisi dapat dikatakan sebagai identitas dari suatu masyarakat setiap daerah yang telah dilakukan secara turun temurun yang berasal dari nenek moyang di setiap daerah (Prayogi, 2016). Kearifan lokal memiliki peran bagi setiap orang yang melestarikan dan mempertahankannya di setiap daerah. Peran merupakan gambaran interaksi sosial dalam terminologi actor-aktor yang bermain sesuai dengan apa ayang ditetapkan oleh budaya. Harapan yang terdapat pada peran pada umumnya merupakan pemahaman bersama yang menuntun individu untuk berperilaku dalam kehidupan sehari - hari. Harapan akan peran tersebut dapat berasal dari peran itu sendiri, individu yang mengendalikan peran tersebut, masyarakat atau pihak lain yang berkepentingan dengan peran tersebut. Teori peran juga menyatakan bahwa perilaku yang diharapkan oleh individu tidak konsisten, mereka dapat mengalami stress, depresi, merasa tidak (Hutami dan Chariri, 2010). Peran kearifan lokal salah satunya adalah berperran terhadap interaksi sosial. Kearifan lokal akan menimbulkan bentuk interaksi atau hubungan sosial di masyarakat. Hubungan sosial adalah hubungan timbal balik individu dengan individu, indovidu dengan kelompok dan kelompok dengan kelompok. Ciri-ciri hubungan sosial yaitu : adanya dua orang pelau atau lebih, adanya hubungan timbal balik, diawali dengan kontak sosial, dan mempunyai tujuan yang jelas. Syarat terjadinya hubungan sosial yaitu adanya kontak dan komunikasi. Kontak maksudnya hubungan yang terjadi bersifat langsung seperti adanya sentuhan, percakapan, ataupun tatp muka sebagai wujud aksi reaksi sedangkan komunikasi maksudnya penyampaian pesan dari seseorang kepada orang lain yang dilakukan secara langsung maupun dengan alat bantu agar orang tersebut dapat memberikan tanggapan.

Bentuk tradisi ataupun kearifan lokal yang saat ini masih terjaga kelestariannya yaitu tradisi yang ada pada Desa Jatian Kecamatan Pakusari Kabupaten Jember. Tradisi yang sampai saat ini dipertahankan di Desa Jatian Kecamatan Pakusari Kabupaten Jember adalah tradisi Nyunteng, Mayarakat di Desa Jatian Kecamatan Pakusari Kabupaten Jember di zaman modern sistem tradisional. Petani padi yang ada di Desa Jatian pada umumnya masih melakukan tradisi yang sudah ada sejak dulu yaitu tradisi Nyunteng guna mempertahankan kearifan lokal di daerah setempat.

Penelitian ini bertujuan untuk mendeskripsikan kearifan lokal Nyunteng yang ada di Desa Jatian Kecamatan Pakusari Kabupaten Jember. Kegiatan "Nyunteng" ini dilakukan dengan melibatkan masyarakat sekitar dalam kegiatannya. Masyarakat yang terlibat dalam kegiatan "Nyunteng" ini tidak hanya sesama petani, akan tetapi juga melibatkan masyarakat sekitar yang berasal dari sektor pertanian dan sektor non pertanian. Pemaparan terkait kearifan lokal "Nyunteng"di atas kemudian melatarbelakangi peneliti dalam melakukan penelitian untuk mengetahui (1) bagaimana proses pelaksanaan kearifan lokal Nyunteng yang ada di Desa Jatian Kecamatan Pakusari Kabupaten Jember dan (2) bagaimana peran dari kerarifan lokal Nyunteng dalam hubungan sosial petani pangan yang ada di Desa Jatian Kecamatan Pakusari Kabupaten Jember.

\section{METODE PENELITIAN}

Penelitian dilakukan di Desa Jatian Kecamatan Pakusari Kabupaten Jember. Desa Jatian Kecamatan Pakusari Kabupaten Jember merupakan Desa yang sampai saat ini masih mempertahankan dan melestarikan kearifan lokal nyunteng. Pendekatan dalam penelitian kualitatif pada umumnya lebih berorientasi terhadap fenomena atau gejala yang bersifat alami yang ada di lapang. Teknik analisis data yang digunakan dalam penelitian ini adalah Miles and Huberman, dimana menurutnya metode analisis data dapat dilakukan dengan

Novikarumsari et.al ( Peran Kearifan Lokal Nyunteng dalam Hubungan Sosial Petani Pangan di Desa Jatian Kecamatan Pakusari Kabupaten Jember, Local Wisdom, Tradition, Culture, Nyunteng, Role, Sosial Relations) 
beberapa tahapan yakni pengumpulan data, reduksi data, penyajian data, dan pengambilan keputusan.

\section{HASIL DAN PEMBAHASAN}

\section{Proses Pelaksanaan Kearifan Lokal Nyunteng di Desa Jatian Kecamatan Pakusari Kabupaten Jember}

Kearifan lokal Nyunteng merupakan salah satu bentuk tradisi yang saat ini masih dilestarikan di Kabupaten Jember, tepatnya di Desa Jatian Kecamatan Pakusari. Kearifan lokal Nyunteng pada umumnya dilakukan oleh petani pangan khususnya petani padi yang ada di Desa Jatian. Kegiatan Nyunteng digunakan sebagai identitas dari sistem pertanian tradisonal yang ada di Desa Jatian. Masyarakat di Desa Jatian Kecamatan Pakusari Kabupaten Jember sampai saat ini mempercayai dan meyakini adanya tradisi Nyunteng.

Nyunteng merupakan tradisi yang dilakukan secara turun - temurun di Desa Jatian Kecamatan Pakusari yang berasal dari nenek moyang di daerah tersebut. Petani padi di Desa Jatian melakukan tradisi Nyunteng di sawah mereka masing. - masing, kecuali petani penggarap yang ikut melaksanakan di sawah garapan milik orang lain. Pelaksanaan kearifan lokal Nyunteng rutin dilaksanakan oleh petani sebelum pelaksanaan panen padi. Petani padi di Desa Jatian Kecamatan Pakusari Kabupaten Jember melaksanakan kearifan lokal Nyunteng dengan membawa berbagai sesajen ke sawah secara bersama - sama dengan masyarakat yang turut berpartisipasi di dalamnya.

Proses pelaksaan kearifan lokal Nyunteng dilakukan sebagai ungkapan rasa syukur dan ungkapan rasa terimakasih kepada Tuhan Yang Maha Esa karena telah memberikan kesuburan tanah di Desa Jatian . Kearifan lokal Nyunteng juga dilakukan dengan tujuan sebagai ungkapan rasa terimakasih petani pangan kepada leluhur mereka yang membabat tanah di Desa Jatian menjadi tanah yang subur dan produktif. Sesajen yang dibawa oleh petani digunakan untuk serangkaian kegiatan dalam proses Nyunteng yang ditujukan kepada Tuhan dan leluhur atau nenek moyang mereka.

Pelaksanaan kearifan lokal Nyunteng pada mulanya hanya dilakukan di sawah saja, namun dengan seiring perkembangan zaman, masyarakat melakukan Nyunteng dengan beberapa cara, diantaranya dilakukan secara langsung di sawah, dilakukan di sawah dan di rumah. Pelaksanaan kearifan lokal Nyunteng berdasarkan salah satu informan menyebutkan bahwa ada beberapa pandangan stratifikasi sosial. Petani yang memiliki lahan $<0,5$ ha hanya melaksanakan Nyunteng di sawah atau di rumah saja dengan cara syukuran kecil - kecilan, sedangkan petani yang memiliki luas lahan \pm 1 ha atau petani yang tergolong ekonomi berkecukupan pada umumnya melaksanakan kegiatan Nyunteng di sawah dan rumah secara besar - besaran dengan mengundang warga sekitar atau tetangga di sekitar rumah. Berikut ini merupakan proses pelaksanaan tradisi Nyunteng di Desa Jatian Kecamatan Pakusari Kabupaten Jember yang proses pelaksanaannya dilakukan di tempat berbeda.

\section{a. Proses Pelaksanaan Kearifan Lokal Nyunteng di Sawah (Sederhana)}

Proses pelaksanaan kearifan lokal Nyunteng dilakukan pada sore hari sehari sebelum pemanenan padi di lakukan. Pemilik sawah membawa berbagai sesajen ke sawah bersama keluarga mereka. Pelaksanaan Nyunteng yang dilakukan oleh petani di sawah pada umumnya hanya di lakukan secara sederhana atau kecil - kecilan, yang memiliki 
luas lahan $<0,5$ ha. Petani membawa berbagai sesajen berupa tajin, sepotong ayam, jajanan desa dan nasi tumpeng kecil. Tajin yang dibawa oleh petani sebagai sesajen diletakkan di aliran saluran air yang menuju sawah atau masyarakat sekitar menyebutnya sebagai sangatan. Tumpeng yang dibawa dimakan di sawah bersama - sama oleh keluarga petani dan petani lain atau masyarakat sekitar yang turut berpartisipasi dalam kegiatan Nyunteng. Sesajen lainnya seperti ayam potong dan tajin ditinggal oleh petani di sawah, biasanya diletakkan di pojok - pojok sawah dengan keyakinan masing - masing petani pangan yang melaksanakan kegiatan Nyunteng.

\section{b. Proses Pelaksanaan Kearifan Lokal Nyunteng di Sawah dan di Rumah (Besar - besaran).}

Proses pelaksanaan Nyunteng secara besar - besaran pada umumnya dilakukan oleh petani padi yang memiliki luas lahan \pm 1 ha. Pelaksanaan Nyunteng dilakukan sebanyak dua kali yaitu di sawah dan di rumah petani. Kegiatan nyunteng besar - besaran yang dilakukan di sawah prosesnya sama seperti pelaksanaan secara sederhana yaitu dilakukan pada sore hari sehari sebelum panen, namun yang membedakannya adalah setelah panen, petani pemilik lahan mengadakan syukuran di rumahnya dengan mengundang tetangga dan warga sekitar. Proses pelaksanaan yang dilakukan di rumah adalah dengan acara slametan dengan memberikan nasi dan kue berkat kepada tetangga yang diundang.

\section{Peran Kearifan Lokal Nyunteng dalam Hubungan Sosial Petani Pangan di Desa Jatian Kecamatan Pakusari Kabupaten Jember}

Kearifan lokal Nyunteng di Desa Jatian Kecamatan Pakusari Kabupaten Jember melibatkan seluruh lapisan masyarakat dalam pelaksanaanya baik sesama petani dan non petani serta dari semua kalangan mulai dari anak-anak hingga orang tua. Keterlibatan masyarakat dalam pelaksanaan tradisi nyunteng ini menyebabkan adanya hubungan sosial yang terbentuk di dalamnya, sehingga dapat dikatakan bahwasanya kegiatan nyunteng memiliki peranan dalam mempengaruhi adanya hubungan sosial masyarakat di daerah tersebut.

Pelaksanaan kearifan lokal Nyunteng yang ada di Desa Jatian menyebabkan hubungan sosial antar petani dan antar anggota masyarakat meningkat. Peran kearifan lokal dalam meningkatkan hubungan sosial masyarakat di Desa Jatian Kecamatan Pakusari Kabupaten Jember dapat dilihat dari keterlibatan masyarakat dalam pelaksanaan tradisi ini. Tradisi ini dilaksanakan dengan mengajak masyarakat sekitar untuk ikut serta dalam kegitan ini. Keikutsertaan masyarakat menyebabkan beberapa anggota masyarakat akan berkumpul dan kemudian saling bertukar cerita. Kondisi berkumpulnya sebagian anggota masyarakat ini secara tidak langsung dapat meningkatkan hubugan antara anggota masyarakat.

Pelaksanaan kegiatan Nyunteng yang dilakukan di sawah ataupun di rumah, sama-sama melibatkan warga sekitar. Kearifan lokal Nyunteng yang dilakukan di sawah pada umumnya mengajak petani lain yang berada di sekitar sawah untuk bergabung dalam kegiatan kearifan lokal Nyunteng dan jika terdapat beberapa warga yang lewat disekitar lokasi Nyunteng, maka pemilik lahan akan langsung mengajak warga tersebut untuk ikut serta dalam proses Nyunteng. Kearifan lokal Nyunteng yang dilaksanakan di rumah lebih banyak melibatkan tetangga dan warga sekitar. Acara yang digelar oleh pemilik lahan yang melakukan Nyunteng dihadiri oleh ibu-ibu di Desa Jatian untuk membuat dan 
mempersiapkan segala jenis seserahan dan aneka macam kue yang nantinya akan digunakan di acara slametan setelah Nyunteng. Pemilik lahan akan mengundang warga sekitar setelah panen sebagai ungkapan syukur atas hasil panennya. Tamu undangan berasal dari kerabat, tetangga maupun warga sekitar dari pemilik lahan yang melaksankan Nyunteng. Hubungan sosial yang terjalin akibat dari adanya kearifan lokal Nyunteng berdasarkan pemaparan terkait pelaksaannya, dapat disimpulkan bahwa kearifan lokal Nyunteng memiliki peran dalam meningkatkan hubungan sosial masyarakat Desa Jatian Kecamatan Pakusari Kabupaten Jember. Peran kearifan lokal Nyunteng dalam hubungan sosial diantaranya adalah mampu untuk membangun interaksi sosial antar petani pangan dengan petani lainnya dan masyarakat karena dalam pelaksanaannya tradisi Nyunteng melibatkan beberapa petani dan tokoh masyarakat lainnya. Hal ini sebagaimana Kearifan lokal memiliki peran bagi setiap orang yang melestarikan dan mempertahankannya di setiap daerah. Peran merupakan gambaran interaksi sosial dalam terminologi aktor-aktor yang bermain sesuai dengan apa ayang ditetapkan oleh budaya. Harapan yang terdapat pada peran pada umumnya merupakan pemahaman bersama yang menuntun individu untuk berperilaku dalam kehidupan seharihari. Harapan akan peran dapat berasal dari peran itu sendiri, individu yang mengendalikan peran tersebut, masyarakat atau pihak lain yang berkepentingan dengan peran tersebut. (Hutami dan Chariri, 2010). Kearifan lokal Nyunteng mampu membangun interaksi sosial antara pelaksana kegiatan Nyunteng dengan masyarakat karena Nyunteng dilaksanakan secara gotong royong dan Nyunteng mampu meningkatkan hubungan sosial dan membentuk interaksi sosial remaja dan anak-anak Desa Jatian sehingga sampai saat ini kearifan lokal Nyunteng masih dilestarikan.

\section{KESIMPULAN}

Berdasarkan hasil penelitian yang dilakukan, maka dapat disimpulkan bahwa masyarakat Desa Jatian masih mampu mempertahankan dan melestarikan kearifan lokal Nyunteng sebagai identitas dari desa setempat. Proses pelaksanaan Nyunteng Petani yang memiliki lahan $<0,5$ ha hanya melaksanakan Nyunteng di sawah atau di rumah saja dengan cara syukuran kecil - kecilan, sedangkan petani yang memiliki luas lahan \pm 1 ha melaksanakan kegiatan Nyunteng di sawah sekaligus di rumah secara besar-besaran dengan mengundang warga sekitar atau tetangga di sekitar rumah pemilik lahan. Kearifan lokal Nyunteng berperan dalam meningkatkan hubungan sosial petani pangan dan masyarakat yang ada di Desa Jatian Kecamatan Pakusari Kabupaten Jember karena di dalam pelaksanaannya proses Nyunteng melibatkan beberapa anggota masyarakat mulai dari anak-anak hingga orang tua.

\section{DAFTAR PUSTAKA}

Athanasius, T. 2012. Manajemen Keuangan, Buku Dua, Edisi Kedelapan. Jakarta. Gramedia.

Dila, F. R. 2017. Ritual Keleman Dan Metik Bagi Petani Desa Wonokasian, Kecamatan Wonoayu, Sidoarjo. Paradigma, 5(3):1-13.

Edi dan Hastuti. Kearifan Lokal Dalam Mengelola Sumberdaya Lahan Pertanian di Lembah Sungai Sileng Purba Kecamatan Borobudur. Jom Faperta. 1 (2) : 1 - 18.

Guntur, A., Edi, S., dan Cepriadi. Kajian Kearifan Lokal Petani Padi Sawah Di Desa Hutan Gurgur Di Kecamatan Silaen Kabupaten Toba Samosir. Jom Faperta. 3 (2) : 1 - 7. 
Hutami. G dan A Chariri. 2010. Pengaruh Konflik Peran Dan Ambiguitas Peran Terhadap Komitmen Independensi Auditor Internal Pemerintah Daerah (Studi Empiris Pada Inspektorat Kota Semarang) .Standar Profesional Akuntan Publik. 19(9):1148-1159.

Prayogi R dan E. Danial. 2016. Pergeseran Nilai-Nilai Budaya Pada Suku Bonai Sebagai Civic Culture Di Kecamatan Bonai Darussalam Kabupaten Rokan Hulu Provinsi Riau. Humanika. 23(1):61-79.

Sidabutar, O S, Sayamar E, Kausar. 2016. Strategy for Maintaining a Local Wisdom in Rice Farming in Simpang Raya Village Panei SubDistricts Simalungun District North Sumatra Province. JOM Faperta Vol. 3 No. 2 Oktober 2016. 